\title{
STATUTORY IMPLEMENTATION OF DOUBLE JEOPARDY CLAUSES: NEW LIFE FOR A MORIBUND CONSTITUTIONAL GUARANTEE
}

THE constitutional prohibition of double jeopardy ${ }^{1}$ has been so eroded by judicial decisions that its meaning today bears little resemblance to its meaning at the time when it was incorporated into the Federal Constitution. Partly due to confusion of substantive and adjective law, and partly through judicial failure to modify doctrine in order to implement underlying policies under changed circumstances, double jeopardy decisions are frequently both illogical and irreconcilable. Proper implementation of the policies underlying double jeopardy provisions requires simultaneous solution of several interdependent problems of procedural and substantive law. These are not likely to be encountered in any one case, so that solution of present difficulties by the courts appears both difficult and unlikely, if not impossible. A legislative attack upon the problem therefore seems desirable, and has been proposed from time to time.2 This comment will discuss certain judicial doctrines which appear to disregard the objectives of constitutional prohibitions against double jeopardy. It will then examine two proposals for legislative solution with a view to determining the extent to which they afford more adequate implementation of these policies. It will, finally, suggest alternative emphases and approaches that may assist in future attempts to draft a double jeopardy act.

\section{Historical Background and Policy Objectives of the Double JEOPARDY Rule}

The prohibition against double jeopardy found in the federal and most state constitutions ${ }^{3}$ represents two distinct policies: that no person should be punished more than once for the same offense, ${ }^{4}$ and that no one should be harassed

1. U.S. CoNst. amend. V. "[N]or shall any person be subject for the 'same offense to be twice put in jeopardy of life or limb."

2. See text at notes 66-68 infra.

3. All but five of the states have double jeopardy provisions in their constitution; the phraseologies vary. For citations see ALI, Administration of CRminal Law: DnUBLE JEOPARDY 56-58 (1935) (hereinafter cited as ALI DRAFT). Throughout this comment reference to "constitutional provision" includes both state and federal constitutiunal prohibitions against double jeopardy.

4. Ex parte Lange, 85 U.S. (1S Wall.) 163, 169, 173 (1873) ; see Morgan v. Devine, 237 U.S. 632 (1914); Ebeling v. Morgan, 237 U.S. 625 (1914). See also People v. Savarese, 114 N.Y.S.2d 816 (Sup. Ct. 1952), for discussion of state decisions.

The penal codes of two states have express statutory prohibitions against double punishment. Cal. Pen. Code $\$ 654$; N.Y. Pen. Law $\$ 1938$. The other jurisdictions, which have constitutional prohibitions only against double jeopardy nevertheless treat imposition of double punishment as double jeopardy. See discussion in People v. Savarese, supra; 24 C.J.S., Criminal Law 1990 (1941).

Since Exx parte Lange, supra, the Supreme Court has not held squarely that multiple 
by successive prosecutions for a single wrongful act or activity. ${ }^{5}$ The ban on multiple punishment imposes a limitation on judicial interpretation of substantive criminal law. It forbids penalizing an accused more severely than the law provides, through the device of finding that he has committed several violations of substantive law where only one exists. ${ }^{6}$ The restriction on multiple prosecutions, on the other hand, is designed to implement several procedural objectives. One of these is protection of both the defendant and the public from the expense of prolonged and unnecessary litigation due to the retrial of previously adjudicated issues, ${ }^{7}$ or to the use of several proceedings to try

punishment for a single offense, in addition to being an erroneous interpretation of the statute making the offense punishable, also violates the double jeopardy clause. In modern context the question arises primarily where an accused is incorrectly awarded cumulative sentences on separate counts of a multiple count indictment, which together should only make out a single substantive offense. See Note, 57 Y AL.E L.J. 132 (1947). The distinction between holding imposition of more than one penalty for a single offense to be mert "erroneous sentencing" and regarding it as void on constitutional grounds is that in the former case it is reviewable only by direct appeal, while in the latter situation it is open to collateral attack by writ of habeas corpus. See Peters, Collateral Attack by Habcas Corpus, 23 WASH. L. REv. 87, 91-92 (1948). On an appeal from original proceedings the constitutional question need not be reached, since an appellate tribunal can review imposition of several sentences as a matter of statutory construction. See Bell v. United States, 349 U.S. 81 (1955). But in Holiday v. Johnston, 313 U.S. 342 (1940), Justice Roberts stated by way of dictum that "the erroneous imposition of two sentences for a single offense of which the accused has been convicted ... does not constitute double jeopardy." $I d$. at 349. This phrase has led to confusion among lower federal courts, causing some of them to hold that double jeopardy prohibits only successive prosecutions, not multiple punishment. See notes 57-58 infra and accompanying text. However, Supreme Court adherence to the doctrine of Ex parte Lange is indicated by several cases which arose on habeas corpus where the court, without discussing the appropriateness of the writ, determined on the merits whether multiple punishment was improper. E.g., Morgan v. Devine, supra; Ebeling v. Morgan, supra; see United States v. Mitchener, 331 U.S. 789 (1947) (affirming denial of motion to vacate second sentence).

5. The policy has found expression in the maxim "no one shall be twice vexed for the same cause" (nemo debet bis vexari pro una et eadem causa). For discussion of the origin of the maxim and its policies, see Perkins, Crminal LAw and Procenure 650 (1952) ; Ex parte Lange, supra note 4. The words "act or activity" are used here in preference to the more customary "offense" since the latter is not as accurate a synonym for the maxim's phrase "one and the same cause." Although the early common law implemented the maxim by prohibiting retrial for the same "offense," in practice, retrial of any aspect of the same factual transaction was generally precluded. See notes 13-20 infra and accompanying text.

6. See note 4 supra.

7. The maxim that "no one ought to be twice vexed for the same cause," "found expression in the common law in the form of the plea of res judicata in civil suits and in the pleas of autrefois acquit and autrefois convict in criminal prosecutions." PEREINS, $a p$. cit. supra note 5, at 650 . For the connection between the pleas of autrefois acquit or convict and the double jeopardy clause of the Constitution, see note 13 infra. For discussion of the policy of res judicata, see Angel v. Bullington, 330 U.S. 183, 186, 192 (1947); Clark, Modern Pleading 761-66 (1951) ; Note, 64 Yale L.J. 436, 442 \& n.43 (1955). While res judicata and double jeopardy reflect very similar policies, they are not synonymous. See discussion at notes 55-61 infra. 
questions of fact and law that logically make up a single case. ${ }^{8}$ Another objective is to safeguard the accused from the excessive harassment and stigma of repeated criminal prosecutions. ${ }^{9}$ Furthermore, once acquitted or convicted of crime for his conduct in a particular transaction, a defendant should be able to consider the matter closed and plan his life ahead without the threat of subsequent prosecution and possible imprisonment for the same conduct. ${ }^{10}$ These three procedural objectives-economy of time and money, avoidance of unnecessary harassment and stigma, and psychological security-are expressed in the maxim that "no one shall be twice vexed for the same cause."11

The substantive and procedural goals underlying the double jeopardy concept need not necessarily operate in the same case. An accused may be subjected to the harassment of successive prosecutions without ever being convicted, in which case the problem of multiple punishment never arises. On the other hand, as the result of a single prosecution he may be found guilty of, and punished for, several offenses where his acts should only give rise to a single criminal liability. ${ }^{12}$

Prior to the adoption of the Federal Bill of Rights the common law recognized both policies of double jeopardy, ${ }^{13}$ but when the rules for implementing these

8 . The statement in the text is currently accepted only in a minority of jurisdictions. Ste State v. Greely, 30 N.J. Super. 180, 185, 103 A.2d 639, 642 (1954) : “[T] he separation into its components, for the purpose of a separate prosecution, of an episode that constitutes a single criminal act" is the essence of double jeopardy. For the majority view, see United States v. Brimsdon, 23 F. Supp. 510, 512 (W.D. Mo. 1938) : "The constitutional guaranty is against jeopardy for the same offense. There is no constitutional guaranty against a repetition of evidence in trials for different offenses." But see authorities cited notes 14-20 infra and accompanying text, showing that the early common law achieved the results now reached under the minority rule.

9. State v. Hoag, 36 N.J. Super. 555, 114 A.2d 573 (App. Div. 1955) ; Hurst v. State, 86 Ala. 604, 6 So. 120 (1889); Palko v. Connecticut, 302 U.S. 319, 328 (1938) (dictum) (constitutional provision serves to prevent state from wearing down an accused by multiple trials). The stigma, harassment and anxiety which a criminal prosecution entails have most frequently been recognized in cases involving the constitutional right to speedy trial. See Ex parte Pickerill, 44 F. Supp. 741 (N.D. Tex. 1942) ; Note, 64 YaLe L.J. 1208, 1212 (1955).

10. See United States v. Candelaria, 131 F. Supp. 797 (S.D. Cal. 1955) (rehabilitation ingyossible where further prosecution threatened); InTERstate Commission on Crine, Hanionok on Interstate Crme Control 85-86 (1947) (same).

11. See note 5 supra.

12. See discussion in notes $43-45$ infra.

13. At common law there was no plea of double jeopardy as such, but four pleas in bar: autrofois acquit, autrefois conzict, autrefois attaint and former pardon. However, the term "former jcopardy" was known at common law and was used by Blackstone in describing these pleas. 4 Blackstone, Comanentaries $* 335$.

Two of the four pleas prevented only multiple prosecution. However, antrefois convitit and autrefois attaint barred multiple punishment as well. That goal was also recognized in the maxim "Nemo debet bis puniri pro uno delicta." 4 Coke, Reports 43 (a). Blackstone mentions it as the reason why an appeal by a private individual, demanding punishment for the offender, could not be prosecuted against a defendant convicted after prosecution by the King, although the appeal would lie if there had been an acquittal. Buackstone, Commentaries $* 314$. With this exception the problem of multiple punish- 
objectives were first devised there was little need for sharp distinction between them. By modern standards the number of separate legal categories of criminal offenses was relatively small, and the scope of each offense was comparatively large. ${ }^{14}$ For this reason when courts developed the rule barring second prosecutions for the same "offense" they were not distinguishing between the legal theory of an offense and the underlying factual transaction. ${ }^{\mathbf{1 5}}$ In practice judges compared prior and subsequent indictments, and if the facts alleged in the second had been set forth in the first, the plea was sustained. ${ }^{10}$ In view of the high conviction rate, ${ }^{17}$ moreover, and the fact that conviction for any felony meant death or deportation, ${ }^{18}$ there was little incentive for prosecutors to urge a narrower concept of offense in order to subject an accused to two trials or double punishment by making one criminal transaction the subject of several

ment invariably arose at common law in the context of a second prosecution, since only one penalty could be imposed at a single trial. See note 20 infra.

14. At the end of the thirteenth century, apart from treason and three offenses which were fast falling into the category of misdemeanors, there were but six felonies. 2 PoLloci \& Martland, History of Englis Law 470 (2d ed. 1952). By Coke's time the number had increased to twenty-seven, and in Blackstone's day-roughly the time of the adoption of the United States Constitution-there were 160. 2 STEPHEN, CRIMINal LAw of ENGLAND 219 (1883). The greatest increase was in statutory crimes in the nature of larceny, since many "quasi-thefts" did not fall into any common law criminal category. These statutes generally related to particular types of transactions, such as embezzling an employer's goods, or stealing from a weaving works or a spinning mill. Consequently a man was not apt to commit more than a single legal offense in the course of any of these proscribed transactions. See Plucknetr, Concise Hrstory of the Common Law 423-24 (4th ed. 1948).

In Ex parte Lange, 85 U.S. (18 Wall.) 163 (1873), the United States Supreme Court extended double jeopardy felony treatment to misdemeanors. For common law treatment of misdemeanors, see 4 Blackstone, op. cit. supra note 13 , at $300-15$; Plucknet, op. cit. stipra, at 429-33.

15. The indictments of the middle ages were not concerned with setting forth the technical wordings without which later indictments were held fatally defective. The entire criminal transaction was set forth bluntly and succinctly. Putnam, Procendngs Before Justices of THE PEACE cxxxiii (1938). Thus a fourteenth century indictment alleges in six lines of Latin that the prisoner raped the prosecutor's wife and abducted her, and carried off his goods and chattels. Id. at 406 (indictment No. 18). The word "felony" is written in the margin; but which felony the draftsman had reference to is left to conjecture. A collector of indictments from the period finds it impossible to categorize them according to offenses; the law of the times was concerned more with evidentiary facts than with definitions of "offense." $I d$. at cliii. Gradually indictments increased in length, technicality and number of counts. Eventually, although only a single offense was charged, the indictment described everything the accused had done or might have done in perpetration of the crime. See 1 Stephen, op. cit. supra note 14, at 277-90. Thus the justices, by comparing the first indictment with the second, could readily ascertain whether the accused had previously been tried for any of these facts; and if he had, the plea was held good. See notes 16, 19 infra.

16. E.g., Rex v. Segar, Comb. 401, 90 Eng. Rep. 554 (K.B. 1696); see also note 15 supra.

17. See Note, 57 Yale L.J. 132 \& n.1 (1947).

18. Purnar, op. cit. supra note 15, at cxxxiv (1938); 1 Stephen, op. cit. supra notu 14 , at $291 ; 4$ Blackstone, Commentaries $* 375-77$. 
indictments. However, by the seventeenth and eighteenth centuries, when the number of offenses was larger and it was more customary to frame pleadings in terms of legal theories rather than factual transactions, an occasional attempt was made to retry an accused for a separate legal offense based on the same facts. The courts rejected these efforts at second prosecutions. ${ }^{19}$ Since at common law an indictment could charge only a single felony, and since only one sentence was awarded on any indictment, ${ }^{20}$ two penalties could be imposed only as a result of two trials. Therefore, the common law rule prohibiting a second trial for the same "offense" operated to bar multiple punishment as well as multiple prosecution.

The development of a common law doctrine aiding the defendant was prompted by factors such as the severity of criminal penalties, the disproportionate trial advantages held by the prosecution and the disabilities suffered by an accused. ${ }^{21}$ On the other hand, rigid technicalities of common law pleading and proof, which often operated to cause acquittal without regard to the merits of a case, ultimately gave rise to opposing tendencies. Motivated by a desire to give the prosecution one fair try at convicting the defendant on the merits, courts were led to restrict application of double jeopardy. ${ }^{22}$ Thus in the leading case of The King

19. In Rex v. Segar, Comb. 401, 90 Eng. Rep. 554 (K.B. 1696), defendants were acquitted of burglary by breaking and entering followed by theft within. On a subsequent attempt to indict them for larceny of the same articles, a new offense, the court held that "they could not be indicted a-new for the same fact." Accord, Turner's Case, Kel. 30, 34 Eng. Rep. 1068 (K.B. 1664). The first indictment, on which the defendant was acquitted, alleged breaking and entering with intent to steal the goods of $A$; a subsequent indictment, for the same breaking and entering to steal the goods of $B$, was not allowed. The justices suggested that, since theft of $B$ 's goods was not mentioned in the first indictment, prosecution for that offense might be allowed. Jones and Bever's Case, Kel. 52, 84 Eng. Rep. 107\& (K.B. 1665) (same). Contra, The King v. Vandercomb \& Abbott, 2 Leach 708, 168 Eng. Rep. 455 (Ex. 1796).

20. 1 Chitry, Criminal Law 170 (1st ed. 1819); 1 Stephen, op. cit. supra note 14, at 508. If one felonious act could bear several constructions, each construction could be set forth separately in a different count, unless this amounted to alleging two separate legal offenses. Saunders, Precedents of Indictments 20-22 (2nd ed. 1889). In the event separate offenses were joined in separate counts, sentence could be entered on one count only. 1 CHITTY, op. cit. supra, at 172.

Even today some states by decision or statute adhere to the strict common law rule that an indictment may allege only one offense. Orfiedd, Criminal Procedure 259 (1947).

21. Radin, Anglo-American Legal History 228-29 (1936). An accused in felony cases was first granted the right to summon witnesses in his behalf in 1702 . Not until $1 \$ 37$ were felony defendants allowed counsel, and not until 1898 could they testify in their wwn behalf. Plucknetr, op. cit. supra note 14 , at 410-12. The accused was not allowed to know the charges preferred against him until the indictment was read to him immediately before trial, and he was never allowed to see indictment. Moreover, he could have no hooks or papers to assist him in his defense. 1 STEPHEN, op cit. supra note 14, at 330-32, 350-400. Involuntary confessions and jury attaint were used freely until the seventeenth century.

22. Note, 57 Yale L.J. 132, 133 (1947). See 1 StepHen, op. cit. supra note 14, at $284-86$ for an account of the see-sawing of trial advantages where technicalities favoring either side became excessive. 
7. Vandercomb $\&$ Abbott, ${ }^{23}$ decided in 1796, the definition of "offense" was narrowed to equate it with the legal theory on which the defendant had been tried. Consequently a second trial based on the same factual situation alleged in the first indictment, but proceeding under a new legal theory, was not barred by the rule proscribing a second trial for the same offense.

The disadvantages to the accused and the technicalities resulting in unmerited acquittals, which furnish a historical explanation for double jeopardy doctrines, have been substantially modified under modern criminal procedure, ${ }^{24}$ but the increasing number of penal statutes, along with the rise of the multiple count indictment, have created new problems. The tendency of modern penal legislation has been toward more detailed specification of criminal offenses, so that a single criminal act or transaction comes under the proscription of a steadily increasing number of statutes. ${ }^{25}$ Moreover, these statutes are usually enacted piecemeal over a long period of time. Consequently, they overlap and seldom specify to what extent a given provision is intended to supplement or replace other applicable statutes. ${ }^{26}$ The problems created by this development have been heightened by the trend toward "catchall" indictments charging violation of all provisions of the criminal law which are even remotely relevant. ${ }^{27}$ These factors increase considerably the possibility of multiple prosecution for the same criminal conduct on different theories of liability, as well as the danger of multiple punishment either as a result of successive prosecutions or on a multiple count indictment.

\section{Need for Legislative Revision of Present Double Jeopardy Law}

Largely because of failure to confront the underlying policies which the double jeopardy concept was intended to implement, current court decisions in this area are hopelessly irreconcilable. ${ }^{28}$ Much of this confusion, with its attendant erosion of the double jeopardy clause as a constitutional protection, is due to judicial failure to recognize that new rules must be devised to cope with the fact that a single factual situation may today give rise to a number of substantive offenses. ${ }^{29}$ But while courts have not been willing to make the sweeping re-examination of double jeopardy doctrines that seems required if

23. 2 Leach 708, 168 Eng. Rep. 455 (Ex. 1796). On the first trial the defendants, who had been caught red-handed, were acquitted because of strict rules of variance. To allow a retrial it was necessary to overrule Turner's Case, Kel. 30, 84 Eng. Rep. 1068 (K..B. 1664), and Jones \& Bever's Case, Kel. 52, 84 Eng. Rep. 1078 (K.B. 1665). See note 22 supra.

24. See, generally, Orfield, Criminal Procedure (1947).

25. See, e.g., Bozza v. United States, 330 U.S. 160 (1947) ; Fleischer v. United States, 91 F.2d 404 (6th Cir. 1937) ; People v. Devlin, 143 Cal. 128, 76 Pac. 900 (1904); Note, 7 BrooklyN L. Rev. 79 (1937).

26. See note 25 supra; Note, 57 YaLE L.J. 132 (1947).

27. See $i d$. at 139.

28. Lugar, Criminal Law, Double Jeopardy and Res Judicata, 39 IowA L. REv. 317, 328 \& n.45 (1954); Note, 7 Brookry LN L. Rev. 79, 88 (1937). See also the conflicting cases cited in Commentary to ALI Drart.

29. See notes $37-41$ infra and accompanying text. 
this constitutional protection is to be made effective, they have traditionally heen willing to expand or contract application of these doctrines to fit their own conceptions of the equities in the case before them. ${ }^{30}$ Yet without articulation of the underlying equitable considerations courts repeat old formulas developed at a time when different historical considerations prevailed. ${ }^{31}$ This makes the outcome of a double jeopardy plea highly unpredictable. Not only are the precedents confused, but it is difficult to forsee whether in a given case a court will apply the old rules mechanically or will attempt to improvise. ${ }^{32}$ I glance at the illogical results which courts have reached should demonstrate how illusory the protection of the double jeopardy provision has become.

The common law rule allowing an accused to plead his former jeopardy to bar a second trial for the same offense did not lead to multiple trials for the same criminal activity under different offense categories until after the adoption of the Federal Constitution. ${ }^{33}$ Subsequently, however, in cases where it appeared that a single criminal act or activity violated several provisions of substantive law, courts permitted separate prosecutions for each legal offense. ${ }^{34}$ As a result of this act-offense dichotomy, almost all the states as well as the federal courts now restrict a plea of former jeopardy to second prosecutions based on the same set of facts present in the earlier suit and involving the same provisions of the criminal law. ${ }^{35}$ This makes it possible to put an individual accused of a single criminal act through as many separate trials as there are statutory provisions prohibiting it. ${ }^{36}$ With the enormous growth in the number of statu-

30. An excellent example of this tendency is State v. Fredlund, 200 Minn. 44, 273 N.W. 353 (1937), where the court departed drastically from its earlier double jeopardy rule to allow a second manslaughter prosecution. Not mentioned in the opinion is the fact, pointcd out in the prosecution's brief, that after the first trial two of the defendant's witnesses pleaded guilty to perjury in his behalf. See Note, 24 Mrnn. L. Rev. 522, 561-62 (1940). See also Lugar, supra note 28 , at 344-46.

31. See note 30 supra. See also United States v. Michener, 157 F.2d 616 (8th Cir. 1946), rcv'd, 331 U.S. 789 (1947) ; Note, 57 YALE L.J. 132 (1947).

32. Lugar, supra note 28 , at $328-29$.

33. See note 19 supra.

34. See ALI DRAFT $\$ 5$, commentary for the various tests which have been adopted to determine what constitutes the same offense. And see notes $42-47$ infra. Whatever test is used to ascertain the offense, however, it is the number of offenses, not the essential idcntity of the act or acts giving rise to the separate offenses, which determines the number of prosecutions that may be brought in the federal courts and in all but nine of the states. See Note, 7 Brooklyn L. REv. 79, 81 (1937). However, the difference between the nine states purportedly applying a different rule and the other jurisdictions is rifen negligible. See notes $48-51$ infra.

35. ALI DRAFT $\$ 5$, commentary.

3i. "The test is not whether the defendant has already been tried for the same act, but whether he has been put in jeopardy for the same offense. A single act may be an offense against two statutes; and if each statute requires proof of an additional fact that the other does not, an acquittal or conviction under either statute does not exempt the defendant from prosecution and punishment under the other." Morey v. Commonwealth, 108 Mass. (12 Browne) 433, 434 (1S71). This is the "strict constitutional" test and may he modified by the statutory provisions themselves. See People v. Savarese, 114 N.Y.S.2d R16. (Sup. Ct. 1952). Even states applying the "strict constitutional" test may, however, 
tory crimes, many of them directed to the same areas of criminal activity, the act-offense rule leads to extremely unsound procedural results. For example, as a result of present sex offense statutes an accused may be subjected to five or more separate criminal trials for a single act of intercourse. ${ }^{37}$

When criminal activity that was formerly considered a single violation of substantive law is broken down into numerous component parts, each of which is separately proscribed by statute, the substantive and procedural objectives underlying the double jeopardy concept must be implemented separately rather than jointly as at common law. If by a single muscular contraction a man violates several provisions of substantive law, his act may justify cumulative imposition of the sanctions imposed under each of these provisions, but it does not necessarily follow that a new trial is justified for each such offense. In such a case, even though resort to different provisions of the criminal law in imposing sentence might not be imposition of multiple punishment, ${ }^{38}$ use of separate trials to litigate the accused's guilt for each of the substantive offenses committed in the same criminal transaction may well violate the double jeopardy policy against multiple vexations..$^{39}$

Present doctrine not only makes the number of permissible trials depend on the number of punishable offenses, but various subordinate doctrines for determining what constitutes a separate "offense" insure the finding of an inordinate number. Much of the legislation creating new crimes and subdividing old ones has been enacted piecemeal, with no directives to the courts indicating whether these laws are to be applied cumulatively or alternatively where both appear applicable to the same fact situation. ${ }^{40}$ But in addition, courts have avoided all examination of probable legislative intent in such situations by adopting a presumption that the bare existence of several statutes seemingly applicable to the same set of facts indicates a legislative intent to make all such provisions cumulatively applicable. ${ }^{41}$ The same result is also reached by em-

make exceptions for the "lesser included affense." See note 43 infra. For statutory inhibitions on multiple prosecutions, see note 66 infra.

For a discussion of the problem that arises when an act is prohibited by statutes of more than one jurisdiction, see notes 132-36 infra and accompanying text. Statutes and local ordinances may both prohibit the same act. See State v. Tucker, 137 Wash. 162, 242 Pac. 363 (1926), allowing separate prosecutions under each, and reviewing authorities.

37. Note, 7 BrookLyN L. Rev. 79, 82 (1937).

38. See discussion in notes 117-37 infra and accompanying text.

39. Horack, The Multiple Consquences of a Single Criminal Act, 21 Mrns. L. KEv. $805,821-22$ (1937). Where the prosecution wants liability for several offenses adjudicated in one proceeding, there is no bar to joinder of offenses in separate counts or to cumulative punishment for all the offenses of which the accused is found guilty. See Note, 57 Y ALE L.J. 132 (1947). To the extent that multiplicity of prosecutions is unnecessary, it would seem to constitute harassment. For discussion of compulsory joinder in civil actions, see notes 96-97 infra and accompanying text.

40. See Kirchheimer, The Act, The Offense and Double Jeopardy, 58 YaLE L.J. 513, 515-16 (1949).

41. See, e.g., Burton v. United States, 202 U.S. 344, 377 (1906) ; Bozza v. United States, 330 U.S. 160 (1947) ; People v. Devlin, 143 Cal. 128, 76 Pac. 900 (1904). 
ploying certain traditional "tests" of double jeopardy which, although they consider only procedural and evidentiary factors, are used to determine the number of substantive offenses, and hence both the number of trials and the number of permissible punishments. Thus they not only violate the prohibition against successive prosecutions but result in several punishments for the same offense as well.

Most of the tests employed by courts to determine the number of offenses for which an accused may be tried and punished are variations of the "same evidence" test which was originated in The King $v$. Vandercomb \& Abbott. ${ }^{42}$ In its most common form this test permits a second trial except where the same proof will sustain a conviction under both the first and the second indictments. ${ }^{43}$ Although the rule was developed to perform the procedural function of determining whether there should be a second trial, ${ }^{4+}$ it is used also to

42. As originally laid down by Buller, J., in The King v. Vandercomb \& Abbott, 2 Leach 708, 720, 168 Eng. Rep. 455, 461 (Ex. 1796), the rule was: "[U]nless the first indictment were such as the prisoner might have been convicted upon proof of the facts contained in the second indictment, an aquittal on the first indictment can be no bar to the second..."

The negative of this rule permits a second trial unless the evidence sufficient to support a conviction on the second indictment would have warranted conviction on the first. There is another formulation entitled "Buller's rule backwards," and still another combining the rule and the rule backwards. These and other variations are discussed in Lugar, stpra note 23, at 321-23; Note, 7 Brooklyn L. Rev. 79, 82 (1937). See also ALI Draft 26.

43. E.g., Morgan v. Devine, 237 U.S. 632, 639 (1915), citing Bishop, Crininal LAw $\$ 1052$ (2d ed. 1892) ; State v. Fredlund, 200 Minn. 44, 273 N.W. 353 (1937); State v. Marchindo, 65 Mont. 431, 211 Pac. 1093 (1922). Courts using the same verbal description of the test do not reach the same results, however. See ALI DRAFT $\$ 5$ Commentary.

The lesser included offense doctrine, an exception to the same evidence test, provides that when a defendant has been placed in jeopardy of conviction of one offense, he cannot be prosecuted for another which is a lesser element of the first. E.g., People v. Raymond, 87 Cal. App. 510, 262 Pac. 442 (1927). Sometimes prosecution for the lesser offense will bar trial for the greater. E.g., Franklin v. State, 85 Ga. 570, 11 S.E. 876 (1890). Where the initial trial for the lesser offense was before a court without jurisdiction to try the greater offense, however, or where on an initial trial for the greater offense the defendant could not have been convicted for the lesser, the result is otherwise. See Commonwealth v. McCan, 277 Mass. 199, 178 N.E. 633 (1931). It will readily be seen that the lesser included offense doctrine is often merely the same evidence test in different words. Thus if defendant is indicted for murder, and the jury on the first trial can return a verdict of manslaughter, an acquittal on the first trial acquits him of both murder and manslaughter. A second trial for manslaughter would require the same evidence that would have been necessary to sustain a conviction for that "lesser included offense" on the first trial. It has been suggested that a better reason for barring second prosecutions, whether the first trial is for the lesser or the greater offense, is that the offenses are mutually exclusive or alternative: a defendant has committed either murder or manslaughter, never both. Kirchheimer, supra note 40, at 516-17.

44. In The King v. Vandercomb \& Abbott, 2 Leach 708, 168 Eng. Rep. 455 (Ex. $1796)$, the question was whether the allegations of the second indictment were sufficiently different from those on the first indictment to bar a plea of autrefois acquit, and the same evidence test was employed to rationalize denial of the plea. But had the question arisen after conviction on the first indictment it is unlikely that the court would have reached the same result, since there was no doubt in Vandercomb that only one substantive offense 
ascertain the existence of separate substantive offenses. Its present operation illustrates how judicial confusion of substantive and adjective law has nullified the policies of both. For example, where the legislature creates the substantive offense of grand larceny, defining the crime as the wrongful taking of more than $\$ 100$ from the possession of another, and a man steals $\$ 500$, it would seem he has committed but one offense whether the theft was of a single $\$ 500$ bill or five $\$ 100$ bills. In the latter case, however, the same evidence test sustains five separate offenses triable separately and punishable cumulatively because each bill has a different serial number- different evidence for each offense $!^{45}$ It thus not only leads automatically to a finding of separate offenses wherever more than one statute is involved, it may also split a single violation of the same statute into several distinct offenses.

The "same transaction" test was adopted by some courts to limit piecemeal prosecution by forcing the state to prosecute at one trial all offenses committed with a common motivating intent aimed at a single ultimate goal. ${ }^{46}$ Applied logically this test offers considerable possibility for bringing the procedural aspect of double jeopardy into consonance with the aims of modern criminal law administration. It would seem to entail repudiation of the act-offense dichotomy and with it the same evidence test as a measure of permissible prosecutions. It would seem as well to make unity of an underlying factual transaction determine the number of prosecutions, meanwhile allowing recognition that a transaction may give rise to separately punishable offenses. However, where the equities of a case appeared to call for a second trial, courts purporting to apply this rule have had no difficulty in permitting successive prosecutions for technically separate offenses, even though they were in fact committed in the course of a single criminal transaction. ${ }^{47}$ Even worse, many courts have confused substance and procedure by finding a separate transaction for each

had been committed. The prosecution had lost the first trial due to a variance between allegations and proof as to the date when the crime had taken place. The second indictment alleged the correct date, and the court held (because this was different evidence) that a new trial was allowable.

45. See, e.g., Commonwealth v. Butterick, 100 Mass. (4 Browne) 1, \&-9 (1868) (embezzlement of several bonds at same time from same person); Barton v. State, 23 Wis. 587 (1869) (five drafts forged at same time on same sheet of paper); Johnson $v$. Commonwealth, $201 \mathrm{Ky} .314,256 \mathrm{~S} . \mathrm{W} .388$ (1923) (seventy-five hands of poker dealt in one game). But of. Bell v. United States, 213 F.2d 629 (6th Cir. 1954), rev'd, 349 U.S. S1 (1955) (transporting three women at once in violation of Mann Act); ALI DKAFT $\$ \$ 5$, 22 \& Commentaries. Fortunately not many courts have carried the logic of the same evidence test to this extreme where there is one victim, where the same provision of the criminal law is involved, and where the different articles are similar in nature. Ibid. Where different persons are affected by a single act, however, the act is almost invariably held to constitute separate offenses. See notes 122-24 infra and accompanying text.

46. Spannell v. State, \&3 Tex. Crim. 418, 203 S.W. 357 (1918). For a variation of the "same transaction" test which in effect restricts it to cases where the second prosecution is for the "identical act," see State v. Hoag, 35 N.J. Super. 555, 114 A.2d 573 (App. Div. 1955). For a list of jurisdictions using the same transaction test, see Lugar, supra note 28 , at 325 .

47. See notes 30 supra, 48, 49 infra; Lugar, supra note 28 , at 326. 
offense, ${ }^{48}$ or by expanding the scope of the offense to make it coextensive with the transaction. ${ }^{49}$ Inevitably this leads to self-contradiction, and the same transaction test as well as the act-offense dichotomy, embellished by the same evidence test, may all flourish simultaneously in the same jurisdiction. ${ }^{50}$ The consequent confusion surrounding the rule has led to its abandonment in some jurisdictions which had adopted it for a time. ${ }^{51}$

Neither of the two arms of res judicata-collateral estoppel and the rule against splitting a cause of action-is of much benefit to a defendant seeking to avoid piecemeal prosecution..$^{52}$ Some state courts have held that collateral estoppel is not available in criminal cases. ${ }^{53}$ However, the Supreme Court has held that, independently of double jeopardy, collateral estoppel should bar a second prosecution in a federal court where a previous acquittal necessarily constitutes an adjudication favorable to the accused of an issue which must be determined against him to sustain a conviction at a second trial. ${ }^{54}$ But the doctrine has frequently been ignored or applied inconsistently by lower federal courts and those state jurisdictions which recognize it. ${ }^{55}$ The rule against splitting a cause of action, which protects defendants in modern civil proceedings from being forced to defend separate suits against various liabilities arising from a single occurrence, has not been carried over to criminal cases. ${ }^{.56}$ Therefore, except for the limited protection afforded by the same transaction test in a minority of jurisdictions, there is little to prevent prosecutors from planning cases, framing indictments and selecting evidence in such a manner as to secure innumerable prosecutions of the same defendant for the same criminal activity.

48. E.g., People v. Brain, 75 Cal. App. 109, 241 Pac. 913 (1925) (housebreaking and theft within the house) ; State v. Hoag, 35 N.J. Super. 555, 114 A.2d 573 (App. Div. 1955) (each robbery victim of a single holdup); case cited note 51 infra.

49. E.g., State v. Cooper, 13 N.J.L. (1 Green) 361 (1833) (murder and arson one "offense" so as to bar second prosecution); State v. Mowser, 92 N.J.L. 474, 106 Atl. 416 (1919) (murder and robbery one "offense"; conviction of robbery will bar prosecution for murder); State v. Greely, 30 N.J. Super. 180, 103 A.2d 639(L.), aff'd, 31 N.J. Super. 542, 107 A.2d 439 (App. Div. 1954) (same). The last case indicates there may be a distinction between "offense" for the purpose of sentencing and "offense" for the purpose of prosecution. See also cases cited ALI Draft 29-30

50. With New Jersey cases cited note 49 supra, compare State v. Hoag, 35 N.J. Super. 555, 114 A.2d 573 (App. Div. 1955) ; Sylcox v. Dearden, 30 N.J. Super. 325, 104 A.2d 717 (App. Div. 1954) ; State v. Labato, 7 N.J. 137, 80 A.2d 617 (1951) ; State v. Tumbiolo, 28 N.J. Super. 231, 100 A.2d 496 (App. Div.), cert. denied, 347 U.S. 948 (1953) (semble).

51. Lugar, supra note 28 , at 325 . See also Harris v. State, $193 \mathrm{Ga}$. 109, 116, 17 S.E.2d 573,578 (1941), which holds that the same evidence test must be used to determine what is the same transaction. See note 30 stipra, discussing the abandonment of the test in Minnesota.

52. Lugar, supra note 28 , at $329-41$.

53. Ibid.

54. United States v. Oppenheimer, 242 U.S. 85 (1916).

55. E.g., Fall v. United States, 49 F.2d 506, 511 (D.C. Cir. 1931) ; Seymour v. Commonwealth, 133 Va. 775, 112 S.E. 806 (1922). See Comment, 27 TEx. L. Rev. 231, 235 (1918); Lugar, supra note 28 , at 330-41.

56. Id. at 329-41. 
There has also been judicial confusion as to whether double jeopardy proscribes several punishments for a single offense, imposed as a result of a multiple count indictment. Thus some lower federal courts have held that the constitutional guarantee prohibits only multiple prosecutions, not multiple punishments, ${ }^{57}$ while others hare held that the double jeopardy clause forbids both. ${ }^{58}$ Courts in the former group have been influenced by the fact that when the common law rules were first formulated a single prosecution could lead to conviction of only one substantive offense, and that a second penalty could be imposed only after a separate trial.59 These courts have concluded that, where several punishments are imposed on a multiple count indictment which properly alleges only one substantive offense, the multiple punishment is mere "erroneous sentencing" and does not constitute double jeopardy. ${ }^{60}$ The question most frequently arises in the case of an accused who has been awarded two penalties for a single criminal offense, and who seeks to attack the second sentence collaterally by writ of habeas corpus. ${ }^{61}$ It seems unsound to restrict the constitutional protection to the procedural prohibition of a second trial merely because at common law there was no danger of several punishments resulting from a single trial. ${ }^{62}$ Common law courts did effectively prevent multiple punishment for a single crime. ${ }^{63}$ And to the accused it is little worse to be in prison for two cumulative sentences following a single trial than to serve two sentences resulting from separate trials. This is the reasoning which has led other courts, including the Supreme Court, to conclude that multiple convictions for one offense are void and subject to collateral attack as violative of the constitutional prohibition against double jeopardy. ${ }^{64}$

The persistent judicial application of unrealistic double jeopardy doctrines calls for legislative reform. Judges' interpretations of substantive law have often been unsatisfactory; that the cause in many cases has been poor drafting points up the need for statutory remedy. Judicial inertia concerning the procedural problems in the double jeopardy field runs a close parallel to the history of civil procedure prior to modern legislative reforms which have, inter alia, eliminated much excessive litigation through provisions for mandatory and permissive joinder. ${ }^{65}$ And because of double jeopardy's constitutional basis,

57. Calvaresi v. United States, 216 F.2d 891, 902 (10th Cir. 1954); Hensley v. United States, 156 F.2d 675 (8th Cir. 1946); White v. Pescor, 155 F.2d 902, 904 (Sth Cir. 1946). Much of the confusion is apparently attributable to a dictum in Holiday v. Johnson, 313 U.S. 342,349 (1940), discussed in note 4 supra.

58. E.g., Goetz v. United States, 39 F.2d 903 (5th Cir. 1930) ; Tritico v. United States, 4 F.2d 664 (5th Cir. 1925) ; Morgan v. United States, 294 Fed. 82, 84 (4th Cir. 1923).

59. For discussion of early indictment practice, see note 20 supra and accompanying text.

60. See note 57 supra.

61. See Peters, Collateral Attack by Habeas Corpus, 23 WAse. L. Rev. 87, 91-92 (1948).

62. See note 20 supra and accompanying text.

63. See note 19 sipra and accompanying text.

64. E.g., Ex parte Lange, 85 U.S. (18 Wall.) 163, 173 (1873).

65. See 2 Moore, Federal Practice passim (2d ed. 1948); Clark, Code Pleading passim (2d ed. 1947). 
even more than in civil cases the goals of trial convenience and avoidance of multiplicity of suits deserve prompt and effective implementation.

\section{Previous Proposed Solutions}

Although no legislative codification of double jeopardy law has yet been enacted in this country, ${ }^{66}$ proposals for such a statute have existed for some time. In 1935 the American Law Institute published its Official Draft of an Act on Double Jeopardy, and at present the Institute is drafting a Model Penal Code which is to include a double jeopardy section. ${ }^{67}$ That part of the new code, however, has not yet been prepared. A more recent proposal for a Double Jeopardy Act appears in an unpublished preliminary draft of a Code of Correction prepared by the late Professor George $\mathrm{H}$. Dession of the Yale Law School, ${ }^{68}$ at the behest of the Governor of Puerto Rico, for eventual submission to the Commonwealth legislature. ${ }^{69}$ The 1935 ALI draft and Professor Dession's proposals contrast sharply. To suggest features for inclusion in later codifications it may be helpful to make an analytical comparison of the two to determine the extent to which the provisions of either afford desirable implementation of the policies underlying the double jeopardy rule.

\section{The ALI Double Jeopardy Act}

The ALI's 1935 draft of a Double Jeopardy Act is keyed largely to the substantive question of the number of offenses which an accused has committed. If more than one penalty can be imposed, the ALI would allow separate prosecutions without regard to the essential identity of the underlying transaction. ${ }^{70}$

66. A number of states have enacted statutes in the double jeopardy field, frequently expanding constitutional protection where it had been narrowed by courts. See, e.g., People v. Savarese, 114 N.Y.S.2d 816 (Sup. Ct. 1952). For statutory provisions relating to continuing offenses, see note 125 infra. Statutes prohibiting prosecutions by one jurisdiction after trial for the same offense in the courts of another jurisdiction are discussed in notes 130-36 infra. Other statutory enactments on specific questions are listed in commentaries to various sections of ALI DRAFT. These sporadic enactments have dealt only with certain aspects of the double jeopardy problem and in no case represent attempts at general codification of double jeopardy law. Morover, they have frequently been ignored by courts. Kirchheimer, supra note 40 , at 531 .

67. Parts of the ALI MIOdel PeNal CODE have been printed in draft form, such as Drafts 1-4 (1953) dealing with sentencing and treatment of offenders, plan of the code, definitions, and property crimes.

68. Dession, Code of Correction (unpublished manuscript in Yale Law Library 1955) (hereinafter cited as Dessron). Those sections of Professor Dession's draft which are discussed in this comment are reprinted infra, in appropriate footnotes.

69. Clark, George H. Dession, 64 Y ALE L.J. 1103-05 (1955).

70. See note 71 infra.

However, certain sections give limited effect to collateral estoppel. Thus if a defendant is tried for committing one of two offenses which have a third offense as a necessary common element (as rape and incest have fornication as a common element), and he is acquitted, he cannot subsequently be tried for either of the other offenses. This is on the theory that the acquittal negatives the commission of the common offense and therefore of the third offense, since this last can only be shown by proving the common offense. 
The keystone of the ALI draft is its section 5, which provides that prosecutions are for the same offense only where they are "for violations of the same provision of the criminal law and the facts on which they are based are the same."71 The extreme rigidity of this act-offense approach is somewhat relaxed-for "policy reasons"-in subsequent sections. Thus section 22 provides (with an exception discussed below) that if a person is tried for a given offense he cannot be tried again for a violation of the same provision of the criminal law committed in the same transaction. ${ }^{72}$ This provision would eliminate the possibility left open under section 5 that there might be five separate trials and convictions of a man who in a single act steals five $\$ 100$ bills. $^{.3}$

However, section 22 retains the same evidence test where the "different evidence" consists of a showing that the act or acts committed affected different persons. Thus, if each of the five $\$ 100$ bills belonged to a different person, five trials and five punishments would be permitted. This distinction appears to spring from a failure to appreciate a fundamental difference between the policy objectives of criminal law and the law of torts. The function of tort law is to afford compensation to an injured party. ${ }^{74}$ Consequently it is proper to permit an injured plaintiff who has not joined or been joined in an earlier suit to maintain a separate action. But the government prosecutes a criminal suit not to vindicate the rights of individual plaintiffs but to protect the general public. Since from the standpoint of the public-and the thief-only one wrong

Conviction of the common offense must, however, have been possible on the first indictment before this provision can come into effect. A conviction on the first charge, on the other hand, will not bar prosecution for the second. ALI DRAFT $\$ \$ 25,26$. Section 18 would likewise bar a prosecution for an offense alternative to one for which the defendant has been tried, if the evidence would be the same in both cases. For a discussion of alternative offenses see text at notes 119-20 infra.

71. In commenting on this provision the codifiers point out that all courts would agree that a prosecution was for the same offense if it fell within the definition given. In addition, however, courts in certain circumstances hold that two prosecutions are for the same offense even though they are not for violation of the same provision of the criminal law and though they are not based on the same facts. It is correctly pointed out that this result was reached because the courts, believing public policy and fair play forbid prosecution of person a second time even though the offenses alleged in the two indictments were actually different, accomplished the desired result by holding that two offenses were one. See notes 22-23, 47-50 supra and accompanying text. It is stated that the scheme of the draft is to limit the definition of same offense to its "one and true meaning," and then to prohibit in subsequent sections whatever second prosecutions should not be permitted in the interest of sound policy, even though based on different offenses. ALI DRAFT $\$ 5$, commentary. The clear implication, not explicitly stated, is that second prosecutions which do not fall within the definition of $\S 5$ are allowable unless otherwise prohibited.

72. The draftsmen explain this section by connotative definition as follows: Assault and battery committed fifteen times in the same transaction on the same person, only one prosecution; assault and battery, and mayhem, by one blow on the same person, two prosccutions because they are not violations of the same provision of the criminal law. ALI DRAFT $\$ 22$, explanation.

73. Section 5 in this respect is as narrow as the strictest version of the same evidence test. See notes $42-45$ supra.

74. Prosser, Torts 7 (2d ed. 1941). 
has occurred and only one criminal right of action is required no matter how many individuals are adversely affected, allowing more than one trial serves no legitimate purpose.

Another shortcoming of the ALI draft is that it provides no answer to the question whether an accused who has stolen five bills-regardless of ownership -might be found guilty on a multiple count indictment of five substantive offenses and be subjected to cumulative imposition of the sanction for each such offense. From the wording of section 22 , stating that "a person . . . acquitted or convicted of an offense ... shall not again be prosecuted for a violation of the same provision of the criminal law committed in the same transaction. . .," it would seem that the draftsmen of the Act still regard each blow struck in the course of an assault, or each bill stolen from a wallet, as a distinct substantive offense, separately punishable though not always separately triable. But it is not clear whether the ALI in this section intended to redefine substantive offenses or merely to enact a procedural test to compel joinder of offenses. If the ALI intended the latter, it is strange that the draft does not specifically provide for joinder of such offenses on a multiple count indictment and indicate the consequences of nonjoinder. On the other hand section 5 , defining "offense," appears to imply that an accused should be neither tried nor punished for separate offenses if separate prosecution is prohibited elsewhere in the chapter. If the draftsmen wanted to prohibit multiple punishment whenever multiple prosecution would be barred, they should have provided that a contrary result could not be reached by using a multiple-count indictment. ${ }^{75}$

Had the ALI confined itself to codifying the existing irrationalities of court decisions on double jeopardy, its results might be understandable. But the ALI draft contains several major innovations against the overwhelming weight of authority in this country; it would, for example, allow state appeal. ${ }^{76}$ Originally the restriction of the double jeopardy plea to second prosecutions based on the same "offense" and "facts" alleged at the first trial was to grant

75. The cutting and slashing of seven mail bags is specifically stated to result in only one prosecution under $\$ 22$. In Ebeling v. Morgan, 237 U.S. 625 (1915), the Court held that where an accused had cut and slashed seven mail bags in one transaction, Congress intended there should be seven offenses, punishable cumulatively. Section 22, if construed to bar multiple punishments, would thus use a procedural rule to change substantive law.

76. ALI Draft $\$ 13$. Section 14 provides that retrial after appeal by the state is not a subsequent prosecution for the same offense but is a continuation of the original prosecution. For present practice concerning state appeal, see notes 105-12 infra.

Further, $\$ 6$ provides that the fact "that a person has been put on trial for an offense is not a bar to a subsequent trial of such person for the same offense unless on the former trial he was acquitted or convicted." Most states now hold that jeopardy attaches when a jury is empaneled, although the rule is so riddled with exceptions that many cases reach the same result as the ALI. See note 87 infra.

In one respect the ALI would liberalize double jeopardy practice. Section 15 provides that acquittal or conviction on the same facts in the court of one jurisdiction bars a prosecution based on the same facts in another jurisdiction. For the current majority rule on this point see notes 131-36 infra. 
the prosecution one fair hearing of its case on the merits where the accused had gone free in the first trial due to an error of the court or some technicality of pleading or proof. ${ }^{77}$ However, these technicalities have been remedied, and the ALI, by allowing state appeal, would assure the prosecution of a fair trial on the merits. Nevertheless, the ALI would retain the hair-splitting doctrines with regard to "offenses" and "facts" that were developed to overcome these disadvantages to the prosecution.

\section{The Dession Double Jeopardy Act}

Professor Dession's proposals, on the other hand, go further than the present law of any Anglo-American jurisdiction in proscribing multiple prosecutions for fact situations susceptible of final determination in one proceeding. ${ }^{78} \mathrm{His}$ draft would require that the scope of a criminal trial be determined, for double jeopardy purposes, on the basis of the operative facts, without regard to the substantive law involved. "An act, omission, practice or transaction, or two or more such connected together, or constituting parts of a common scheme or plan," must be joined in a single trial, and a series of similar violations is considered an entity for purposes of prosecution. ${ }^{79}$ The government may bring the accused to trial under any or all provisions of substantive law applicable to the component parts of such a situation. 80 To achieve a balance against

77. See text at notes $22-23$ supra.

78. For modern British practice, which allows but does not require joinder of offenses arising from the same transaction, see Orfrein, Criminal Procedure 200-03 (1947).

79. "Sec. 62. Principle of Stabilization.

A situation subject to correction or any combination or series of related situations shall be evaluated in context, as a whole, and with fnality within a reasonable time; and all indicated measures of correction, including claims for reparation arising out of the situation, shall so far as possible be determined and coordinated in a single proceeding.

"Sec. 63. Proceeding under More than One Provision Permitted.

Where an act, omission, practice or transaction, or two or more such connected together, or constituting parts of a common scheme or plan, constitute a situation subject to correction prescribed by more than one provision of this Code or other law, a proceeding may be instituted under any or all such provisions.

"Sec. 64. Limitation on Number of Corrective Determinations.

Where an act, omission, practice or transaction, or two or more such connected together or constituting parts of a common scheme or plan, constitute a situation subject to correction prescribed by more than one provision of this Code or other law, or by a provision of the foregoing and by the laws of another jurisdiction, a corrective determination or determinations for the respondent on the merits under one provision shall bar a subsequent proceeding against him under any other applicable provisions."

80. Dession $\$ 63$. Under $\$ 62$, civil suits for damages may be consolidated with a criminal trial. Professor Dession was aware that in a later draft more specific provisions would have to be added concerning the conditions under which such a consolidation might take place. Presumably it would be necessary to provide that both parties must consent. Since the burden of proof is higher in a criminal suit than in a civil action, and since it would be unreasonable to expect the same jury to acquit a defendant on a criminal charge and yet to return a verdict against him for damages, the plaintiff might be given the opportunity to elect to take damages if the defendant were found guilty of the criminal charge, or to institute a separate suit. On the other hand, to try the issue of civil liability along 
the requirement that the state be allowed only one trial where formerly it had been possible to litigate the guilt of an accused in several proceedings, Professor Dession's draft would allow for state appeal and retrial for material errors of law, such retrial to be considered as part of a single proceeding. ${ }^{81} \mathrm{~A}$ trial on the merits under one provision, however, would bar subsequent proceedings under any other applicable provisions. ${ }^{82}$

By requiring a single trial of all questions of an accused's criminal liability that logically and conveniently may be tried in one proceeding, this formulation goes far toward achieving the procedural policy objectives of stability, economy and security. ${ }^{83}$ However, as a result of Professor Dession's emphasis on pro-

with the question of criminal responsibility might prejudice the defendant. There are also such questions as whether the private party could be represented by separate counsel in the criminal suit, and whether he could present evidence independently of government counsel. Professor Dession's untimely death leaves to conjecture the manner of dealing with these questions, and for that reason the desirability of a consolidation of civil and criminal actions in one suit is not discussed here. These provisions in $\S 62$, like certain other innovations in the same chapter of the Code, see notes $82,84,85$ infra, although not traditionally considered to be double jeopardy problems, are discussed here in order to indicate the broad scope given by Professor Dession to the principal of stabilization.

81. "Sec. 67. Appeal by the Commonwealth and New Trial.

Where a proceeding has resulted in a judgment of acquittal or dismissal, the Commonwealth shall have the right to appeal from any rulings thought to involve material errors of law prejudicial to the Commonwealth; and on such appeal the judgment or disposition may be revised or reversed and a new trial of any issue or issues or a total trial de novo granted. Appealable rulings include:

(1) Any final order or judgment adverse to the Commonwealth made before jeopardy has attached or after waiver thereof;

(2) Any order granting a new trial;

(3) Any judgment or disposition not authorized by law; or

(4) Any judgment or ruling adverse to the Commonwealth upon any question of law arising during the trial.

"Sec. 68. New Trial not a Distinct or New Proceeding.

Any new trial granted in a corrective proceeding, whether on application of the respondent or of the Commonwealth, shall not be deemed a distinct or new proceeding but rather a continuation of the original proceeding. On such new trial there may be a verdict, finding, judgment or disposition adverse to the respondent in respect of any situation alleged in the original information irrespective of the verdict, finding, judgment or disposition in the former trial."

82. Dession $\$ 64$, reprinted note 79 supra. It will be noted that the phrase "for the respondent" in $\$ 64$ might lead to different results in the event of conviction than in the case of acquittal. Thus if the defendant is acquitted of the murder of $X$, under $\$ 64$ he could not be tried subsequently for a robbery of X committed in the course of the "murder." However, if he were convicted of the murder, that would constitute a determination against him in the first proceeding, and he could subsequently be tried for the robbery. Such a result would be clearly inconsistent with the stated objectives of $\S 62$. On inquiry from the Yalc Lazi Journal, Professor Dession advised that he planned to omit the words "for the respondent" in a later draft to bring the terms of $\S 64$ into consonance with those of $\$ \S 62,63$.

83. There is an apparent inconsistency between $\$ \$ 62-64$ of Professor Dession's Code, reprinted in note 79 supra, and $\$ \$ 65-66$ which provide:

"Sec. 65. Corrective Determination of Included Situation Permitted.

In any proceeding based on a situation subject to corrective measures applicable to 
cedural objectives, his double jeopardy chapter has no general provisions dealing with the problem of multiple punishment. ${ }^{84}$ Consequently, the completed part of his code does not indicate how the question of the number of substantive offenses for which an accused may be convicted and sentenced is to

such situation or to a lesser included situation, but not both; and a judgment, whether adverse, acquittal or dismissal in a corrective proceeding shall bar any subsequent corrective proceeding against the same respondent conditioned on an included situation, and vice versa. An included situation may be any of the following:

(1) A situation the definition of which does not prescribe any essential factual element in addition to thase prescribed for the situation alleged in the information;

(2) A situation involving a less serious class of homicide than that alleged;

(3) A situation the same as that alleged except that negligence rather than purpose is prescribed;

(4) An attempt to bring about the situation alleged; or

(5) A situation involving assault or attempted battery when the situation alleged involves rape, robbery, aggravated battery, or an attempt to commit any of these. "Sec. 66. Continuing Situations.

A situation shall be deemed a single entity so long as the continuance of such situation is uninterrupted. The institution of a corrective proceeding based on such situation, inter alia, shall be considered such an interruption."

It will be noted that $\$ 65$ is essentially a codification of the "lesser included offense" doctrine now employed with variations in most jurisdictions. See note 43 supra. Its wording differs from that of $\$ 64$, however, in that $\$ 65$ provides that a judgment "whether adverse, acquittal or dismissal" shall bar a subsequent proceeding, whereas $\S 64$ provides that a trial "on the merits" operates to bar a second prosecution under any other applicable provision of the criminal law. Since a dismissal may not reflect the merits of the case, use of that term in $\S 65$ raises the question whether the "on the merits" provision in $\S 64$ is dispensed with in the case of situations enumerated in $\$ 65$. Thus where robbery and murder occur in the same transaction, $\$ 65$ would not be applicable, and one of the offenses would have to be tried on the merits under $\$ 64$. But where assault and rape occur in a single transaction, a dismissal for one, though not on the merits, would still bar a subsequent prosecution for the other. Section 65(5) goes further than present law of "lesser included offense"; for assault has not usually been considered a lesser included offense in situations involving rape or robbery. See Kirchheimer, The Act, the Offense and Double Jeopardy, 58 Y ALE L.J. 513,518 (1949); ALI DRAFT 42-52.

Section 66 adds to the provisions of $\S \$ 63-64$ defining "situation" by emphasizing that a situation is considered an entity regardless of the length of time it continues. In part, it codifies present law on the "continuing offense." See notes 124-26 infra.

84. But see $\$ 69$ :

"Sec. 69. Consolidation of Dispositions.

Where the Court shall be disposed to order a disposition involving custody of a subject who is also wanted by the authorities of another jurisdiction on a criminal charge or conviction involving a further sentence of custody or the possibility thereof, and who is or in due course will be subject to removal, extradition or rendition to such other jurisdiction, the Court shall take such other sentence or the possibility thereof into account in arriving at its own disposition, and the Attorney General may exercise the power granted by Part III of this Code to contract with the authorities of such other jurisdiction for the custody and care within the correctional system of the Commonwealth of persons committed to custody by the authorities of such other jurisdiction, and vice a'ersa: Provided, however, that no person shall be committed to custody pursuant to the foregoing without his consent in a juris- 
be resolved. ${ }^{85}$ In the case of a man who is accused of stealing two horses belonging to $A$ and $B$ from the same barn on the same night, Professor Dession would clearly permit only one prosecution. But his draft leaves open the possibility which the same evidence test has created under present law: that two consecutive punishments may be imposed though there might only be one if both horses belonged to one owner. ${ }^{86}$ As has been noted, so far as the thief and society are concerned the criminal activity is the same in either case. To allow the number of punishments to turn on the incidental fact of ownership seems almost as serious a violation of the double jeopardy safeguard as to permit ownership to determine the number of prosecutions.

\section{Pretrial Vexations: The Experimental Indictment}

Since most jurisdictions today hold that "jeopardy" does not "attach" until a jury is empaneled to try the defendant, ${ }^{87}$ an individual may be subjected to the harassment and stigma of criminal prosecution for years without ever being brought to trial. Under the present indictment practice a prosecutor may, when confronted with a case in which certain elements are difficult if not impossible of proof, confine the allegations of his indictment or information to those matters he believes can be successfully proved at trial. If the lower court holds

diction other than that wherein the adverse judgment or conviction on which such custody depends was handed down."

Sue also note $\$ 5$ infra. Moreover, we are concerned here with the general part of the code; Professor Dession indicated to the Yale Law Journal that a contemplated second part dealing with specific offenses would resolve some of the questions raised in the text. Furthermore, chapter 12 of the General Part entitled "Economy of Deprivation," read in the context of the General Part as a whole, indicates that the entire approach to the imposition of penal sanctions differs so radically from current practices that the problem of multiple punishment might not arise under this Code in the same context that it does under current law. The Code is designed to correct entire situations viewed against the background of an accused's personality and behavior history, rather than to fix penalties for specific statutory offenses. See, e.g., Dession $\$ 71$. And $\$ 74$, reprinted at note 85 infra, provides general directives for resolving one of the traditional act-offense dichotomy problems.

85. Section 74 is an exception.

"Sec. 74. Preference for Specificity of Prescription.

Where two or more provisions of law defining categories of situations subject to correction appear to include a particular situation in issue, that provision which is least general in its terms shall be considered the sole applicable provision: Prozided, however, that nothing in the foregoing shall preclude the applicability of a diverse provision addressed to a different quality of social deprivation involved in the same situation."

86. See notes 73-74 supra and accompanying text.

87. E.g., Cornero v. United States, 48 F.2d 69 (9th Cir. 1931) ; State v. Dickson, 200 Iowa 17, 19, 202 N.W. 225, 226 (1925) (dictum) ; Seale v. State, 158 Tex. Crim. App. 440, 256 S.W.2d 86 (1953). The rule, however, is not without a number of exceptions. See Wade v. Hunter, 336 U.S. 684 (1949).

The Federal Rules of Criminal Procedure place no limitation on the number of indictments which may be brought. See Orfierd, Criminal Procedure 194-265 (1947). 
that these charges do not constitute a punishable offense and if this holding is upheld on appeal, the prosecutor may bring a succession of indictments, enlarging the allegations slightly each time, and appealing each dismissal until he finally gets an indictment on which the defendant can be put to trial. In this way years can elapse between the time the first official charges are made and the day when it is ascertained that the government's allegations even make out a legal offense. ${ }^{88}$ This procedure may provide at least as much "vexation" from a defendant's viewpoint as a short trial followed immediately by a retrial. The ALI draft, following the minority rule, finds no jeopardy until there is a verdict of conviction or acquittal. ${ }^{89}$ Professor Dession's formulation contains no provision on this point. ${ }^{90}$

Use of the term "double jeopardy," which tends to confuse two distinct sets of policy objectives, one procedural and the other substantive, is largely responsible for the unfortunate preoccupation of the courts with the word "jeopardy" in dealing with the problem posed by pre-trial vexations. Without exception, noted authorities have debated the issue of "when jeopardy attaches" in terms of danger of conviction to the accused. ${ }^{91}$ For example, the ALI suggests that a defendant is not in jeopardy until a prima facie case is made out against him because until that point there is no danger of conviction. ${ }^{92}$ Such

8S. The danger of governmental persistence is particularly great in cases with political implications and of wide public interest. See Comment, Trial By Persistence, 4 STaN. L. Rev. 520 (1952). As to susceptibility of prosecutors to political influence, see Comment, 65 YALE L.J. 209 (1955).

The extreme possibilities of trial by indictment are graphically illustrated by the proceedings in United States v. Lattimore, 215 F.2d 847 (D.C. Cir. 1954). Defendant was indicated for perjury on December 16, 1952. It was alleged that he had testified falsely before the second of two congressional committees which had been investigating him since 1950. After ten motions accompanied by exhaustive written briefs and oral argument, the key counts of the indictment were dismissed. Id., 112 F. Supp. 507 (D.D.C. 1953). This dismissal of the crucial count was affirmed. Id., 215 F.2d 847 (D.C. Cir. 1954). Defendant was reindicted October 7, 1954. The government then filed an affidavit of prejudice against the District Judge who dismissed the first indictment. The affidavit was stricken as scandalous. Id., 125 F. Supp. 295, 296 (D.D.C. 1954). After extensive argument the main counts of the second indictment were likewise dismissed. Id., $127 \mathrm{~F}$. Supp. 405 (D.D.C. 1955). The government appealed and the decision was affirmed per curiam. A third indictment was pending in July 1955, when the government announced it would terminate the prosecution. There was, however, apparently no legal reason why the government could not have continued this process interminably. During the three year period between the time Lattimore was first indicted and the date the government renounced its attempts to allege facts sufficient to make out a legal offense, defendant was unable to pursue his profession and was, of course, in constant need of legal services. See N.Y. Times, July $3,1955, \S 4$, p. 2 , col. 2 .

89. ALI DRAFT $\$ \$ 9-10$.

90. See notes $79-85$ supra. Note, however, that the requirement of $\$ 64$ that there be a trial on the merits indicates a later stage than empaneling of the jury.

91. See dissenting opinion of Justice Holmes in Kepner v. United States, 195 U.S. $100,134-37$ (1904), criticizing the "fiction" of the jeopardy rationale and stressing that the defendant in terms of reality is in jeopardy even when he is tried on a defective indictment. See also notes 92-95 infra and accompanying text.

92. ALI DRAFT $\$ \$ 9-10$. 
reasoning would lead to the conclusion that where it develops on appeal, after conviction, that under the available evidence and the applicable rules of law an acquittal was mandatory, the accused has not been in jeopardy because he was never in danger of conviction. ${ }^{93}$ But multiple punishment can be prevented only by interpretation of substantive law, not by procedural rules as to when jeopardy attaches. ${ }^{94}$ On the other hand, the procedural aspect of double jeopardy has little if anything to do with the danger of conviction to which a defendant has been exposed. It refers to harassment of an accused, to the disruption of his life caused by criminal prosecution, and to the expense in time and money-the vexation-involved in prolonged litigation. ${ }^{95}$ Since a great deal of vexation can occur before the trial stage is reached, achievement of the procedural objectives underlying the constitutional ban on multiple jeopardy requires more than mere prohibition of a second trial.

\section{An Alternative Approach for Future Double Jeopardy Codes}

The procedural policies underlying the double jeopardy guarantee can be implemented by legislation directed exclusively to the content of the indictment or information. It should be possible to dispose of the entire problem of multiple prosecutions by defining the scope of the antisocial activities that must be charged in a single indictment, and by providing that a second indictment cannot be brought for any illegal acts, any provisions of substantive law, or any theories of criminal liability applicable to the situation so defined. ${ }^{96}$ If the prosecution is in doubt about the facts or the law it may plead in the alternative. In order that the state not be required to foresee every aspect of a case in advance, it should be permitted with leave of court to amend its indict-

93. This is, in fact, the precise result reached where an accused is tried either on a defective indictment or before a court which lacks jurisdiction over the offense. Courts have held that since the trial judge had no jurisdiction to try the defendant he was not in danger of punishment, since any judgment entered would be void. The legal fiction ignores the fact that in such cases punishment was often actually imposed. See, e.g., United States v. Tyler, 15 F.2d 207 (D. Del. 1926). See also ALI DRAFT $\$ 10$, commentary. The ALI would change this rule to bar a second prosecution if, as the result of an earlier prosecution on a defective indictment, sentence has been partially executed. Ibid.

94. See notes 41-45 supra, 118-19 infra and accompanying text.

95. See discussion at notes $87-88$ supra.

96. FED. R. CRIar. P. S(a) provides that two or more offenses, whether felonies or misdemeanors, may be joined in a single indictment if the offenses are based on the same act or transaction, or on two or more related acts or transactions. Some states by rule of court permit joinder of offenses of the same nature, Simmons v. State, $165 \mathrm{Md}$. 155, 167 Atl. 60 (1933) (nine larcenies) ; Forney v. State, 123 Neb. 179, 242 N.W. 441 (1932) (selling mortgaged property on three different occasions); and even joinder of different offenses committed in the same transaction, State v. Thompson, 139 Kan. 59, 29 P.2d 1101 (1934) (rape and robbery). Other states have statutory provisions allowing joinder of offenses. E.g., N.Y. Code Crm. Proc. $\$ 279$; Wast. Rev. Code Ann. $\$ 10.37 .060$ (1951). A double jeopardy act directed to the content of the indictment might take as its basis a permissive rule such as FED. R. Crim. P. 8(a), and make its provisions as to joinder of offenses mandatory either in whole or in part. 
ment to supply omitted allegations of law or fact. ${ }^{97}$ Upon dismissal of an indictment for insufficiency or some other cause, the prosecution could, by analogy to civil procedure, be given the option of amending or standing on its pleadings and taking an appeal. But dismissal would, like dismissal of the complaint in a civil case, be res judicata not only as to those matters alleged in the indictment, but also as to any charges relating to the same transaction, and a subsequent indictment could be met with a motion to quash. ${ }^{98}$ In jurisdictions which require indictment by grand jury, ${ }^{99}$ amendments materially altering the original charges would need grand jury approval, ${ }^{100}$ but minor changes would not. ${ }^{101}$

97. The Indictments Act of $1915,5 \& 6$ GEo. 5, c. $90, \S 5$, allows for wide judicial discretion in permitting amendments. The court may make such order amending the indictment as it deems necessary to meet the circumstances of the case. Where the required amendment cannot be made without injustice to the defendant, however, it is denied. In Georgia, Kansas, Maryland, Massachusetts, Michigan, Minnesota, New Hampshire, Vermont, Virginia and Wisconsin, states which have no constitutional provisions concerning indictment by grand jury, no objection could be made to such an amendment statute. In Arkansas, Arizona, California, Idaho, Louisiana, Missouri, Montana, Nevada, New Mexico, Oklahoma, South Dakota, Utah and Washington, whose constitutions permit parallel use of indictments and informations, it would seem that a broad amendment statute could not give rise to the objection that it deprived the defendant of the right to indictment by grand jury. The same result should be reached in Colorado, Iowa, Nebraska, North Dakota and Wyoming, where the legislature is empowered to abolish indictment by grand jury. See Orfield, Criminal Procedure 209-12 (1947).

98. See 3 MoORe, Federal Practrce $\$ \$ 15.01-15.16$ (2d ed. 1948) for practice in civil cases in the federal courts.

Apart from one amendment granted as a matter of right prior to filing of a responsive pleading or within twenty days after a pleading is served, all amendments are discretionary with the court. FED. R. Crv. P. 12. A similar provision could be adopted for criminal cases, substituting time of arraignment for service of a responsive pleading. In theory a civil plaintiff can elect to stand on his complaint and appeal, once it is dismissed as insufficient, and rely on obtaining permission from the appellate court to amend if it upholds the dismissal. However, in practice a plaintiff who has a meritorious case will amend his original complaint if he can, rather than appeal dismissal, since the risk is too great that he will not be allowed to amend if the dismissal is upheld. 3 Moore, op. cit. supra, $\$ 15.11$. Adoption of this practice in criminal cases would considerably shorten the time which could elapse before it is determined whether the prosecutor can allege facts sufficient to make out a legal offense.

99. See Orfield, Criminal Procedure passim (1947) for citations to the eight jurisdictions requiring grand jury indictment.

100. Wilburn v. State, 101 Miss. 392, 58 So. 7 (1912) ; State v. Goodrich, 46 N.H. 186 (1865).

101. In many states, statutes permitting amendments of form have been enacted. Sue Note, 37 Y ALE L.J. 383 (1928). Minor changes, including deletions, may be made without statutory authorization. Salinger v. United States, 272 U.S. 542, 549 (1926) ; Ford v. United States, 273 U.S. 593, 602 (1926). But cf. Exx parte Bain, 121 U.S. 1 (1887).

As to purely formal matters, including the addition of new material, amendments should be allowed before or during trial on such terms as will provide a defendant with reasonable notice. Orfield, Criminal Procedure 235 (1947). Largely because of constitutional doubts, however, the Federal Rules of Criminal Procedure have no provision for amendment of indictments. ORFIEID, op. cit. supra, at 235. However, the argument has been advanced that considerable liberalization of amendment practices would not prejudice a de- 
To indicate which matters the prosecution must join in one proceeding, future codifiers should formulate rules of guidance which stress operative facts without regard to substantive theories of criminal liability. ${ }^{102}$ These standards should emphasize the same pragmatic tests of trial convenience and avoidance of multiple presentation of evidence now employed in advanced systems of civil procedure. ${ }^{103}$ While it would be desirable to have a definitive rule such as Professor Dession's by which to determine the precise scope of what should be brought within a single criminal trial, the possibility seems illusory in view of the futile attempts in civil suits to define a "cause of action."104 The best solution may be to enact a general rule, to make plain its objectives, and to exhort the courts to construe the rule broadly in the light of its objectives.

fendant's right to indictment by grand jury. Procedurally the indictment (or information) has two primary purposes: to inform the defendant of the charges against him and to set forth the matters for which he will be tried, in order that, on a plea of former jeopardy, it can be readily ascertained whether the charges are the same as those set forth in an carlier indictment which has already led to trial. See $i d$. at 202. Since the grand jury is concerned only with a cursory outline of the facts as presented by the district attorney rather than with the various theories of criminal liability which the facts might support, its primary function is to determine whether or not the defendant should be put to the burden of defending himself. Once that question is answered affirmatively, grand juries do not quibble with the prosecutor concerning "the legal pigeonholes which best fit the criminal transaction." Kirchheimer, supra note 83 , at 537. In this view, it is as unobjectionable to add a count as to drop one. The latter is permissible. Salinger v. United States, supra.

In New York the constitutional requirement of grand jury indictment in felony cases has not prevented application of a statute providing for amendment of indictments to cunform to the proof. People v. Resnick, 21 N.Y.S.2d 483 (N.Y. City Mag. Ct. 1940). But sec People v. La Barbera, 159 Misc. 177, 287 N.Y. Supp. 257 (Sup. Ct.), rev'd (n) other grounds, 249 App. Div. 254, 292 N.Y. Supp. 518 (4th Dep't 1936) (amendment nut allowed for matters not before the grand jury).

An alternative method of avoiding strict requirements of indictment by grand jury has been liberalization of the rules of variance. In the case of larceny, for example, statutes in Massachusetts and California allow for conviction by any one of three theories on one furm of charge. Cal. Pen. Code Annotations $\$ 952$ (1951); Mass. Ann. Laws c. 277 (1933).

102. The more liberal provisions allowing permissive joinder of offenses already make the factual nature of the transaction the criterion for determining which offenses may be joined. E.g., Fed. R. Crim. P. \$; N.Y. Code Crimr. Proc. \$279; Wash. Rev. Code Ann. $\$ 10.37 .060$ (1951).

Courts do not appear to have had difficulty in using the tests of "underlying transaction" or "two or more acts or transactions connected together" or "constituting part of a common scheme or design" in determining whether use of such permissive joinder has been proper. E.g., Rooney v. United States, 203 Fed. 928 (9th Cir. 1913) ; Dillard v. United States, 141 Fed. 303 (9th Cir. 1905); State v. MeMahon, 145 Wash. 672, 261 Pac. 639 (1927).

103. See Clark, Cone Pleading 476-77 (2d ed. 1947) for the various tests which have heen suggested to enforce the rule against splitting a cause of action in civil cases. "The cssential thing is that there be chosen a factual unit, whose limits are determined by the time and sequence and unity of the happenings." Id. at 143.

104. See Clark, Code Pleading 434-93 (2d ed. 1947). ClaArk, Modern Pleading 687.701 (1952); 2 MIOORE, Federal Practice $\$ 2.06$ \& n.26 (2d ed. 1948); Clark, The Code ("ansi' of Action, 33 Yale L.J. 817 (1924). 
Both Professor Dession and the drafters of the ALI Double Jeopardy Act were correct in seeing that if the number of permissible prosecutions for a single criminal transaction was to be limited, it would be desirable to allow state appeal so that the prosecution would be assured of one fair trial of the defendant on the merits. ${ }^{105}$ Courts have restricted the scope of double jeopardy in many cases precisely because lower court error in the first trial prevented determination of the guilt or innocence of the accused. ${ }^{106}$ Indeed, those courts that give explicit consideration to underlying policy questions seem to be searching for a balance that would grant the prosecution one complete hearing on the merits while avoiding the drawbacks of piecemeal prosecution. ${ }^{107}$ Permitting the prosecution to appeal errors prejudicial to the state committed during trial, and to secure a retrial if such errors are found, should obviate present objections to an extension of the double jeopardy rule. ${ }^{108}$ The interest of the community in convicting the guilty would be advanced under a system that would guarantee one full and fair opportunity to try the case against the accused instead of conditioning allowance of a second trial on the accident of whether more than one "offense" can be squeezed out of a criminal transaction, or on the artfulness of a prosecutor in framing indictments. And a procedure allowing retrial only where error existed should be preferred by an accused to the present system, under which the prosecution may secure retrial without regard to the fairness of the first trial by obtaining a second indictment almost indistinguishable from the first.

Statutory rights of appeal by the prosecution would not necessarily be barred by state or federal constitutions. Many jurisdictions have held that in a criminal case the government may not appeal without legislative authorization. ${ }^{109}$ And a few state courts have held that the constitutional prohibition of double jeopardy precludes a statutory right of appeal, although there are conflicting decisions. ${ }^{110}$ In Kepner $v$. United States, ${ }^{111}$ a divided Supreme Court prohibited a retrial following an appeal by the territorial government in the Philippines. The appeal was authorized by a criminal code adopted by a military governor appointed by Congress. While the majority opinion's discussion of the double jeopardy clause could be interpreted to mean that any government appeal is unconstitutional, the decision might be limited to a holding that Congress did not intend that the governor should permit retrial.112 The latter interpretation

105. ALI DRafT $\$ \S 13-14$; Dession $\$ \S 66-67$.

106. See notes 22-23, 30-32 supra.

107. Note, 24 MrNn. L. REv. 522 (1940).

108. The vehement objections of some commentators to the prohibition against double jeopardy often seem to be directed against the procedures disallowing state appeal, which do not necessarily (see notes 109-113 infra) inhere in a double jeopardy rule. See, e.g., Comley, Former Jeopardy, 35 Y ALE L.J. 674 (1926).

109. Cases cited ALI DRAFT 113-15.

110. Cases cited ALI Draft 115.

111. 195 U.S. 100 (1904).

112. The reasoning of the decision in Kepner was that Congress had by its own action made certain provisions of the Bill of Rights applicable to the Philippines. After reviewing 
might be adopted and a grant of the right to appeal approved, particularly if it were enacted in conjunction with provisions taking a more rational and defenseminded approach to double jeopardy. One rationale for sanctioning retrial following appeal by the prosecution would be to consider it merely a continuation of the original jeopardy. ${ }^{113}$ Our present doctrine denying retrial for error prejudicial to the state was inherited from the rigid procedure of early common law, under which an appellate court could never remand for a new trial but was required to dismiss a defendant if he were erroneously convicted or sentenced, regardless of whether the error favored the accused or the crown. ${ }^{114}$ That such procedural devices do not inhere in the double jeopardy rule appears from the fact that the rule has been changed to allow retrial when the defendant appeals. ${ }^{115}$ These reasons for approving a prosecution right of appeal apply to both state and federal governments. The Supreme Court has already held that a state may allow government appeal without violating the fourteenth amendment. ${ }^{110}$

\section{Multiple Punishment: A Problen of Substantive Law}

After procedural rules are established to limit the number of prosecutions for a particular range of antisocial activity, there remains the substantive question of multiple punishment. If an indictment or information alleges every substantive offense applicable to the facts, a court must decide which offenses are punishable if the accused is convicted. Here, as in the procedural area, much of the difficulty was created by the tremendous increase in the number of statutory crimes which has occurred, with attendant overlapping, duplication and repeal by implication. And the situation has been aggravated by application of procedural rules, such as the same evidence test, to determine the number of substantive offenses. ${ }^{117}$

The primary substantive problem is one of legislative intent, not legislative power, for the legislature can award as many different penalties as it deems desirable for a given act or transaction, or any aspect of an act or transaction,

past judicial decisions indicating that retrial after acquittal on writ of error violates the double jeopardy clause, the court stated: "We have no doubt that Congress must be held to have used these words in the well settled sense as declared and settled by the decisions of this court." Kepner v. United States, 195 U.S. 100, 133 (1904). United States v. Sanges, 144 U.S. 310, 312 (1892), relied on by the court in Kepner, contains a dictum indicating that a statute granting a right of appeal to the government would be upheld.

113. Kepner v. United States, 195 U.S. 100, 134-35 (1904) (dissenting opinion by Holmes, J.)

114. E.g., The King v. Bourne, 7 Adol. \& E. 58, 112 Eng. Rep. 393 (K.B. 1837).

115. Hopt v. People, 104 U.S. 631,635 (1881); 110 U.S. 574 (1884); 114 U.S. 488, 492 (1SS5) ; 120 U.S. 430,432 (1887). "The distinction between retrial where the accused appcals, and where the state appeals, is said to lie in the fact that the accused, to secure a trial free from error, must waive his constitutional protection against double jeopardy. To state such a proposition is to answer it." Kepner v. United States, 195 U.S. 100, 135 (1904) (dissenting opinion).

116. Palko v. Connecticut, 302 U.S. 319 (1937).

117. See text at notes 21-27 supra. 
as long as the statute accords substantive due process of law and avoids the eighth amendment's prohibition of cruel and unusual punishments. ${ }^{118}$ This authority is inherent in the power to make conduct criminal and to penalize it, and is not limited in any meaningful sense by the concept of double jeopardy. For example, since the legislature can make armed robbery a crime punishable by twenty years' imprisonment, it can also pass one statute prescribing ten years' imprisonment for robbery, and another prescribing ten years' imprisonment for carrying a revolver in the course of committing a robbery. Cumulative imposition of sentences on a two-count indictment alleging both the committing of a robbery, and the carrying of a revolver in the course of that robbery, is, therefore, not double punishment for the same offense.

Legislative intent is plain where two statutes are designed to implement different social policies. For example, one statute may fix a fine of $\$ 50$ for the sale of liquor on a Sunday, and a second prescribe a fine of $\$ 50$ for the sale of liquor to a minor. If a dealer sells liquor to a minor on a Sunday, a court that awards two $\$ 50$ fines for the single act has not imposed double punishment. ${ }^{119}$ Nor is there a serious problem of substantive law in the converse of this situation, where offenses are clearly alternative. ${ }^{120}$ It is obvious that a defendant is either an accessory or a principal, or that he is guilty either of murder or of manslaughter; never both. When a double jeopardy question arises in a case involving alternative offenses, it is invariably a question of multiple prosecutions.

On the other hand, there are several situations where legislative intent seems clearly opposed to cumulative punishment, but where courts have awarded it. Where the legislature has fixed a penalty for a type of criminal behavior it is not consonant with legislative intent to vary the penalty according to criteria having no relationship to the conduct sought to be prevented or to the intent of the criminal. For example, in one extreme case where the "same evidence" approach was taken, five penalties were awarded to a defendant who had embezzled five $\$ 100$ bonds in a single misdeed, although he would have received but one penalty if he had embezzled a single $\$ 500$ bond. ${ }^{121}$ More

118. Catrino v. United States, 176 F.2d 884 (9th Cir. 1949); United States v. Noble, 155 F.2d 315 (3d Cir. 1946); United States v. Kafes, 214 F.2d 887 (3d Cir. 1954), ccrt. denied, 348 U.S. 887 (1954).

The only apparent limitation is the proscription of cruel and unusual punishment. U.S. Const. amend. VIII. See Comment, 64 YaLE L.J. 1164, 1187-94 (1955). No act of Congress has yet been declared unconstitutional on this ground. Id. at $1187 \&$ n.126. Cf. Weems v. United States, 217 U.S. 349 (1910) (punishment held unconstitutional as disproportionate to the offense).

119. E.g., Ruble v. State, 51 Ark. 170, 10 S.W. 262 (1889); Blair v. State, 81 Ga. 629,7 S.E. 855 (1888).

120. Kirchheimer, supra note 83, at 516-17; ALI DRAFT § 18; see note 43 supra.

121. Commonwealth v. Butterick, 100 Mass. (4 Browne) 1, 9 (1868) ; Bell v. Unitcd States, 213 F.2d 629 (6th Cir. 1954), rev'd, 349 U.S. 81 (1955) (transporting two women in violation of Mann Act) ; Barton v. State, 23 Wis. 587 (1869) (five drafts forged at same time on same sheet of paper) ; People v. Hewlett, 108 Cal. App. 2d 358, 160, 239 P.2d 150, 152 (1951) (dictum) (two embezzlements from same fund on different dates constituted two offenses, although fund was in continuous possession of defendants). 
frequently courts make the number of separate offenses turn on the number of persons affected by an accused's criminal activity, a standard reflecting policies of the law of torts rather than criminal law. ${ }^{122}$ This result may be appropriate where the legislature has designated the unit of offense in terms of individuals, as would be the case with offenses against the person, such as assault. ${ }^{123}$ But it seems improper where the number of victims bears no relationship to the degree of wrongfulness of the accused's behavior. An individual who steals twenty watches from a watchmaker should not be penalized for twenty different ofienses merely because each watch happens to belong to a different owner. ${ }^{124}$ A more difficult problem is posed by the "continuing offense." It is generally accepted that where proscribed conduct necessarily entails repetition of the same act, or consists of a single intent maintained over a period of time, it may not be split into plural offenses. ${ }^{125}$ Repetition of several acts, any one of which would constitute a legal offense, has not, however, generally been placed in the same category. Where recurrence of a wrongful act in a single transaction serves only to aggravate the social harm done, it would seem logical to treat the series as a single offense, particularly if the intent of the criminal could be as wrongful, and the harm to society as serious, whether it resulted from one such act or many. Thus an individual who strikes several blows at the same person in one fracas, or who in an evening's game of poker plays seventy-five hands, should be held to have committed but one offense. ${ }^{126}$

122. See note 124 infra.

123. See, c.g., Commonwealth v. Melissari, $298 \mathrm{~Pa} .63,148$ Atl. 45 (1929) (murder); State v. Corbett, 117 S.C. 356, 109 S.E. 133 (1921) (same).

124. Courts have nevertheless reached this result. E.g., Oddo'v. United States, 171 F.2d 854 (2d Cir.), cert. denied, 337 U.S. 943 (1949); ALI DRAFT, cases collected in commentaries to $\$ \$ 5,18,22$. Where there is a single intention, a minority of courts have refused to reach this result. Smith v. State, 159 Tenn. 674, 21 S.W.2d 400 (1929) (conviction of manslaughter of one boy, killed by defendant's automobile, bars prosecution for assault of second boy struck at same time on theory of single offense). See Kirchheimer, The Act, The Offense and Double Jeopardy, 58 Y ALE L.J. 513 (1949).

125. In rc Snow, 120 U.S. 274 (1887), is a leading case dealing with the traditional type of continuing offense. Where a statute defines an offense which is inherently continuous and cannot consist of an isolated act (in this case, cohabitation), an indictment cannot break up the offense into different acts or periods, charging each as a separate offense. Similarly, a single conspiracy may be prosecuted only once. "[A] single agreement to commit an offense does not become several conspiracies because it continues over a period of time ... and ... there may be a single continuing agreement to commit several offenses." Braverman v. United States, 317 U.S. 49, 52 (1942). Accord, Frohwerk v. United States, 249 U.S. 204 (1919) ; United States v. General Elec. Co., 40 F. Supp. 627 (S.D.N.Y. 1941). But cf. United States v. Swift, 186 Fed. 1002 (N.D. Ill. 1911), holding that alleged continuance if a conspiracy after prior acquittal constitutes a new indictable offense.

126. Contra, Johnson v. Commonwealth, $201 \mathrm{Ky} .314,256$ S.W. 388 (1923) (seventyfive hands of poker played in a continuous game constitute seventy-five offenses); Wrenn v. State, 82 Tex. Crim. 642, 200 S.W. 844 (1918) (conviction for one game of craps does nut bar conviction of second game played same evening); Parks v. State, 57 Tex. Crim. 569,123 S.W. 1109 (1909) (each throw of dice a separate offense). Most courts have achicved a more desirable result, however, refusing to carry the logic of the same evidence test to such an extreme. E.g., Ellis v. State, 105 Ala. 72, 17 So. 119 (1895) (several shots firsd at same person are one offense); ALI Draft $\$ 22$; Dession $\S 67$. 
In many other situations, however, discovering legislative intent is a more subtle process, and there it would be helpful to have workable guides for statutory interpretation. In one statute, for example, the legislature may fix a penalty of two years for assault, and in another set a penalty of six years for mayhem. Is the six year penalty for mayhem to be added to the two year penalty for assault whenever an assault results in a mayhem? Or since commission of mayhem necessarily entails an assault, did the legislature take the element of assault into account when it fixed the punishment for mayhem? One writer has suggested that where statutes stand in this ambiguous relationship to each other, the one with the greater punishment should be held to consume the lesser, and only a single penalty should be imposed.127 This approach would also merge "attempt" into the substantive offense ${ }^{128}$ and would unite many semi-independent yet generically identical offenses, such as possessing a still and using it to produce liquor-at present two distinct offenses. The same author demonstrates that where a criminal act or activity satisfies both a general and a specific statutory definition, the specific should govern to the exclusion of the general. ${ }^{129}$ Thus, robbing a bank, which could be punished either as robbery or as bank robbery or as both, should be treated as bank robbery alone.

The proposals of Professor Dession and the ALI would both eliminate the anomalous prevailing rule ${ }^{130}$ which permits an individual to be tried and convicted by two jurisdictions for the same offense. ${ }^{131}$ Barring the exceptional instance where the same act may violate separate policies of different sovereigns, ${ }^{132}$ this much criticized rule should be abolished both for sound peno-

127. Kirchheimer, sttpra note 124, at 518. Accord, State v. McLaughlin, 121 Kan. 693, 249 Pac. 612 (1926).

128. Kirchheimer, supra note 124 , at 518 .

129. Kirchheimer, supra note 124, at 517-18. Contra, ALI Drarr $\$ 22$. The principle was apparently rejected in Rosenberg v. United States, 346 U.S. 273 (1954), although, due to the brevity of the argument and insufficiency of preparation, see dissenting opinion of Frankfurter, J., id. at 301 , it is uncertain whether the point was squarely presented and rejected.

130. Dession \$ 68, see note 83 supra; ALI DRAFt § 15. The ALI proposal would bar a second prosecution only in event of conviction.

131. Until United States v. Lanza, 260 U.S. 337 (1922), it was generally believed that the Constitution prohibited dual prosecutions by different sovereignties. See dictum to this effect by Story, J. in Houston v. Moore, 18 U.S. (5 Wheat) 1, 33 (1820) (dissenting opinion). The principle is now so thoroughly solidified in judicial decisions that it can apparently be uprooted only by statute. E.g., Jerome v. United States, 318 U.S. 101 (1943) ; Herbert v. Louisiana, 272 U.S. 312 (1926); In re Morgan, 80 F. Supp. 810 (N.D. Iowa 1948).

132. United States v. Sinegar, 6 U.S.C.M.A. 330, 30 C.M.R. 46 (1955). Accused was convicted of contempt of court in Canada for refusing to answer questions before a coroner's inquest. Subsequently he was tried by court martial for the offense of bringing disrepute on the Armed Forces of the United States by refusing to give required testimony before the court of a friendly nation. At the court martial he pleaded former jeopardy. In this case the two offenses alleged were clearly distinct, and violated separate policy objectives, so that if guilty the defendant could properly be punished for both. But the 
logical reasons and because it entails multiple punishment. ${ }^{133}$ Until statutory action is taken, legislative intent must probably be held to favor such dual prosecutions and penalties because of long standing judicial precedents permitting them. ${ }^{134}$

General legislative directives to guide courts in their interpretation of substantive law would induce greater uniformity and predictability of decision in the double jeopardy field. While complete revision of stubstantive criminal law to eliminate many instances of multiple coverage would be desirable, it may not be feasible. Nevertheless, legislatures could avoid some difficulties of statutory construction by indicating, as new penal acts are passed, the extent to which they are intended to replace prior acts, or are to be applied in addition to existing penalties for proscribed conduct of the same nature. ${ }^{135}$ Even with complete revision, however, there are likely to be problems of statutory interpretation. A future double jeopardy act should provide that when courts are faced with questions of multiple punishment they should consider factors such as (1) whether the illegal acts were a single continuing offense; (2) whether the number of victinus affects the seriousness of an offense; (3) whether one offense consumes another; and (4) whether a specific statute should exclude a general one. Particularly in connection with successive acts violating the same statute, courts should be directed to consider whether in reaching the final result by several acts an accused has done greater damage to society or demonstrated more serious criminal intent than if he had accomplished the same criminal

Canadian court could not adjudicate whether he was guilty of the offense of casting disrepute on the United States Armed Forces, and the court martial could not set itself up to determine what disrupts orderiy administration of Canadian justice. If the accused's guilt of both offenses was to be adjudicated at all, and the policies underlying both the military and civilian law vindicated, two trials before different tribunals were unavoidable.

133. United States v. Candelaria, 131 F. Supp. 797 (S.D. Cal. 1955) (prisoner discharged from prison because threat of prosecution by state for offense of which he had been convicted in federal court nullified corrective and rehabilitative function of imprisonment).

Vehement criticism has come from the courts as well as commentators. See, e.g., United States v. Candelaria, supra; Fox v. Ohio, 46 U.S. (5 How.) 410, 434 (1847) (McLean, J., dissenting opinion); Grant, The Lanza Rule of Successive Prosecutions, 32 CoLuM. L. Rev. 1309 (1932). Some states have adopted laws prohibiting prosecution where the defendant has previously been prosecuted in another jurisdiction for the same act or omission. E.g., Cal. Pen. Cone Annotations $\$ 793$ (1951) ; People v. Spitzer, 148 Misc. 97, 266 N.Y. Supp. 522 (Sup. Ct. 1933) ; Griffin v. State, 57 Okla. Crim. 176, 46 P.2d 382 (1935); La Forge v. State, 28 Okla Crim. 37, 228 Pac. 1111 (1924).

134. For instances where legislatures have acted to prevent such prosecutions see United States v. Candela, 131 F. Supp. 249 (S.D.N.Y. 1954).

135. In certain instances legislatures have clearly expressed their intention to penalize separately different aspects of particular criminal undertakings which, though separable, usually appear in the same configuration. United States v. Glidden, 78 F.2d 639 (6th Cir. 1935 ) ; Miss. Code AnN. $\$ 4448$ (1942) ; N.Y. Pen. Cone $\S 406$. In other instances statutes have specifically provided that punishment shall be imposed under only one statute. See, c.g., statutes collected in ALI Draft 159-60. 
result by a single act. If the answer is in the negative, he should be held to have committed but a single continuing offense. ${ }^{136}$

\section{CONCLUSION}

Since the adoption of federal and state constitutional provisions prohibiting double jeopardy, the danger to defendants in criminal cases of both successive prosecutions and multiple punishments has been greatly increased by the growing number of penal statutes and the rise of the multiple count indictment. Application of old rules for implementing double jeopardy policies to new situations has led to confusion and inconsistency which has very nearly made the constitutional provisions meaningless. Drastic legislative revision of these rules to meet modern conditions is required to assure present day defendants the protection that the double jeopardy clause was intended to provide. Much of the difficulty is due to failure to separate the procedural and substantive aspects of the double jeopardy problem. No statute can solve all the problems of substantive law encountered in regulating the imposition of punishment for related offenses. But only a statute indicating first which matters of law and fact must be tried in one proceeding, and second setting forth the considerations which should control solution of substantive questions, can implement adequately the underlying policies of the double jeopardy concept.

136. Such a provision would overrule such cases as Blockburger v. United States, 284 U.S. 299 (1931), where separate offenses were found (and the maximum penalty imposed for each offense) where the accused illegally sold a quantity of narcotics and then on the same day contracted to sell a second quantity to the same person, the second sale being completed the day following. Had the entire amount of narcotics been handed over the counter at once, there would have been but a single offense and the accused would have received a five year sentence for this aspect of the transaction instead of ten. Results like that reached in Ebeling v. Morgan, 237 U.S. 625 (1915), where an accused received cumulative sentences for seven offenses, because in the course of a mail robbery he had cut and slashed seven mail bags, would likewise be incompatible with the provision suggested. 